\title{
sciendo QUALITY IMPROVEMENT IN THE PRODUCTION COMPANY
}

doi:10.2478/mape-2018-0066

Date of submission of the article to the Editor: 03/2018 Date of acceptance of the article by the Editor: 07/2018
MAPE 2018, volume 1, issue 1, pp. 521-527

\section{Dr Joanna Rosak-Szyrocka \\ Dr Krzysztof Knop}

Częstochowa University of Technology, Poland

\begin{abstract}
The article discusses the quality improvement concept in terms of companies' competitiveness and its operations. The research object is a production company located in Silesia province. We analyzed the quality problems occurring in the company based on the selected quality management tools: Ishikawa diagram and the Pareto-Lorenz. It was presented and discussed basic types of waste occurring in the enterprise. It was proposed improvement actions and highlights the importance of immaterial resources - the company's workers.
\end{abstract}

Keywords: quality, improvement, Ishikawa diagram, Pareto-Lorenz diagram

\section{INTRODUCTION}

The concept of quality according to the Japanese is directly related with continuous improvement and striving for perfection. The result is fewer errors and mistakes as well as more satisfied customer (Czubała, 2006; Hamrol, 2008; Stasiak Betlejewska and Czajkowska, 2017). As noted by Priede (Priede, 2012), quality is a very important and strategic component of competitiveness. The competitiveness of enterprises is the ability to develop and achieve benefitsand profits as well as building a competitive advantage (Dobiegała-Korona and Kasiewicz, 2000). An enterprise that wants to be competitive on the domestic or foreign market should constantly strive for modern solutions and should focus on the high quality of the products / services offered. It is important to do this at any time and aspect of functioning. It is understandable that there are no ready-made solutions or models of behavior that guarantee each company a sustainable competitive advantage and achieve market success. Improving the organization today seems to be one of the key ways to improve the company's operations, strengthen its potential, create added value and, as a result, achieve planned effects (Kacała and Wierzbic, 2015). As notes author (Jazon, 2002) process improvement consists in: elimination of activities that do not add value to the process, introduction of activities that increase the effects and customer satisfaction, as well as those that improve communication between people participating in a given process and introducing control measures to reduce the number of errors that arise at individual stages of the process or preventive measures. Malara (2000) emphasizes that improvement consists in drawing conclusions from the conducted analyzes and audits, and then introducing corrective or preventive actions. All steps are taken to meet the requirements and meet the expectations of customers. In the paper, the subject of the research was the problem of breaking up the finished hook on the part and too much number of down time during work. The research was carried out in a production enterprise, based on selected quality management tools; Ishikawa diagram, Pareto-Lorenzo diagram. The article also analyzed the sources of waste occurring on the production hall during the production process of a single check hook. The aim of the paper is to analyze the problem of the product offered by the company (disintegration of the finished hook), but also problems occurring in the enterprise in 
the field of work organization (too many stops). The analyzed company identified wasteful types and proposed corrective actions.

\section{METHODOLOGY OF RESEARCH}

The research object is a production company dealing in the production of artistic products, socalled metalwork and locksmith. The assortment of the company includes products that are designed to arrange stores in the footwear, clothing and food industries. The research facility produces articles for store equipment, e.g. stands and small household appliances, such as pasta cutters. The plant also produces furniture accessories and small household appliances.

\subsection{Ishikawa diagram}

The quality management tool frequently used by employees in connection with brainstorming is the Ishikawa diagram, in order to reach the location of the cause of the observed phenomenon. The diagram hierarchies certain phenomena and gives an overview of the problematic zones. Figure 1 presents a graphical presentation of the Ishikawa diagram.

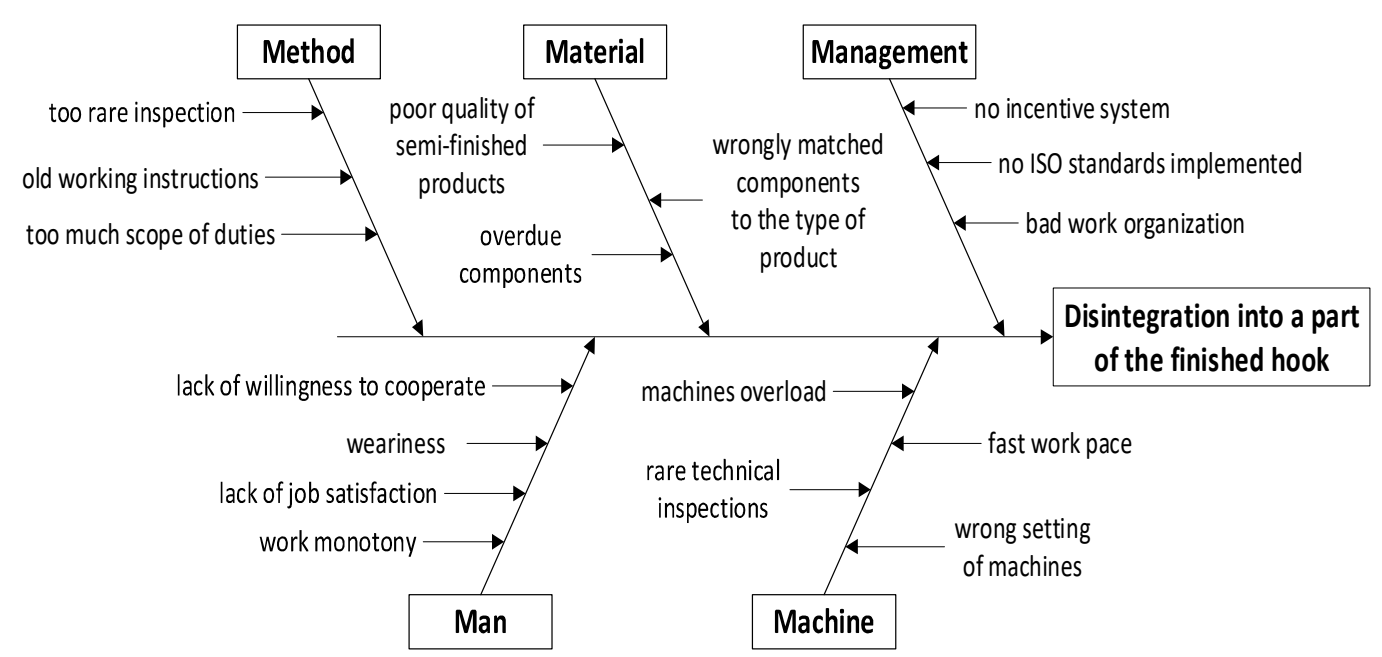

Fig. 1. Ishikawa diagram for the problem disintegration of the finished hook

The analysis of Figure 1 shows that the greatest impact on the decay of the finished hook is related to the material used for its production. The low quality of semi-finished products has a direct impact on the durability of the finished product. Badly matched components cause that the hook on the display screen collapses, its components are bonded unstable and cannot be released for sale, which entails costs associated with repair or disposal. Another important reason that has a significant impact on the disintegration of the ready-made hook are workers - people. Fatigue, monotony and lack of motivation reduce the quality of work, and thus reduce the effectiveness of the company. Employees should be versatile and trained enough to be able to rotate at workstations. Such action should reduce fatigue, because the variety of tasks posed to individual people leads to increased concentration and attention devoted to the tasks performed. Frequent change of position also counteracts monotony at work, people become more involved in the activities entrusted to them. This leads to less errors during the production process.

\subsection{Pareto-Lorenz diagram}

The Pareto-Lorenz diagram (Du, et at., 2018) was used in the research to carry out the analysis of a metalloplastic company. The problem that has been analyzed is the excessive amount of downtime during work. The result of this process was to identify the following causes along with their occurrence (Table 1): 
- Late delivery of materials -2 .

- Defects in components -4 .

- Machine failures - 23 .

- No orders -2.

- Employee errors - 15.

- Poorly constructed schedule -3 .

Table 1

The reasons for the frequency occurrence of a large amount downtime

\begin{tabular}{|l|c|c|c|}
\hline Reasons of occurence & $\begin{array}{c}\text { Number of } \\
\text { occurence }\end{array}$ & $\begin{array}{c}\text { Percentage participation } \\
{[\%]}\end{array}$ & Accumulated value \\
\hline Machine failures & 23 & 46.94 & 46.94 \\
\hline Employee errors & 15 & 30.61 & 77.55 \\
\hline Defects in components & 4 & 8.16 & 85.71 \\
\hline $\begin{array}{l}\text { Poorly constructed } \\
\text { schedule }\end{array}$ & 3 & 6.12 & 91.84 \\
\hline $\begin{array}{l}\text { Late delivery of } \\
\text { materials }\end{array}$ & 2 & 4.08 & 95.92 \\
\hline No orders & 2 & 4.08 & 100 \\
\hline
\end{tabular}

As can be seen from Table 1, the most common reason for the analyzed error were machine failures, the smallest share in this problem was due to delays in the delivery of materials and the lack of orders. Based on Table 1, the Pareto-Lorenz diagram was built (fig. 2). The analysis of Figure 2 shows that $16.67 \%$ of causes, which are the cause of machine failures, cause $46.94 \%$ of all downtime during work.

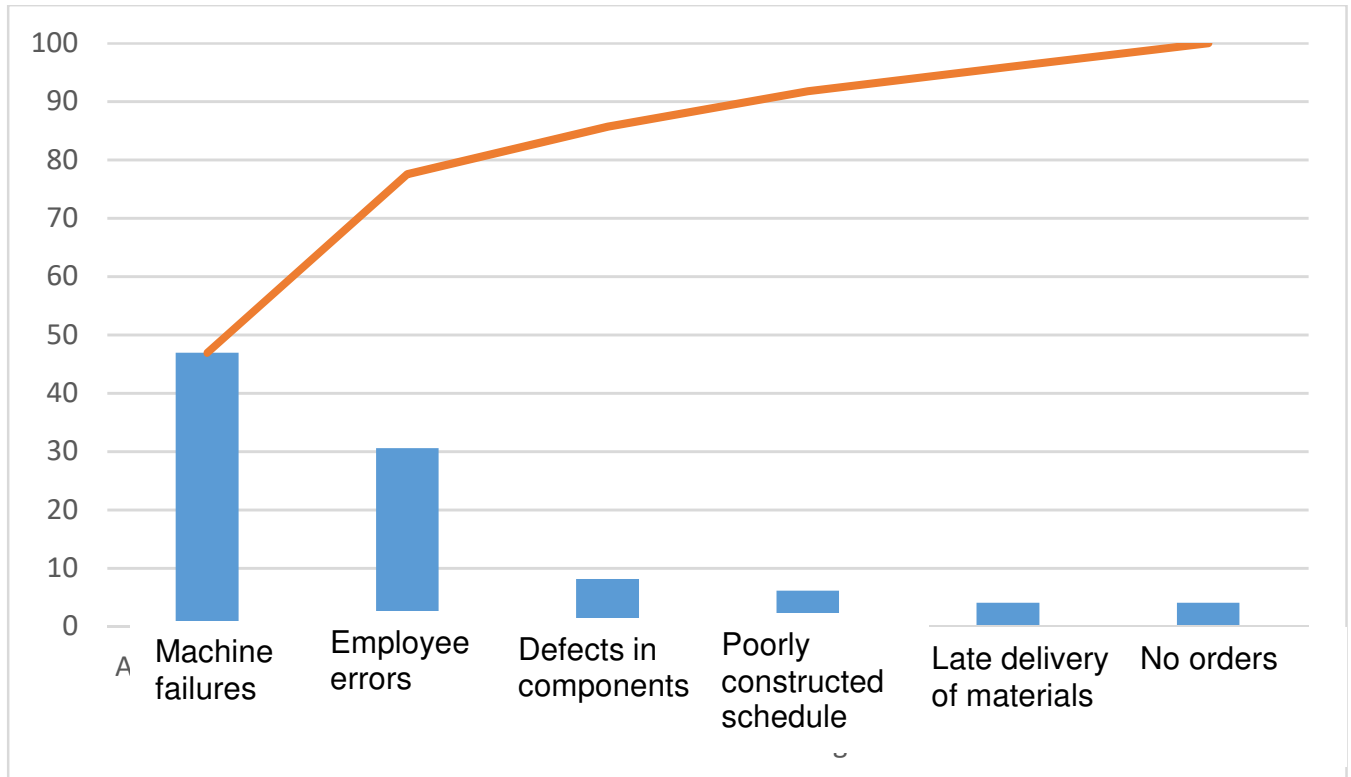

Fig. 2. Pareto-Lorenz diagram for reasons of a large amount of downtime during work

\section{RESULTS}

The elimination of waste is currently one of the most important goals of modern organizations (Womack et al., 2008).The work identified waste places on the production hall during the production process of a single check hook. This product is one of many offered by the company. Depending on the type of orders placed, the employees select the equipment and components for the process, having the following rooms at their disposal: office, main hall, hall 2, paint shop, finished product warehouse, tool shop, semi-finished product warehouse, galvanizing machine shop, packaging hall. Figure 3 shows the organization of the company along with the designations of individual halls and machines. Analyzing the course of the 
production process, several areas generating losses were identified and proposals for changes were presented. Five of the seven possible types of losses were found. The paths of raw material flow and the places of identified areas of waste are depicted in Figure 4. The continuous flow indicates the flow of materials, while the dotted line indicates the flow of information. The following types of waste were distinguished in the analyzed research facility:

1. Unnecessary transport - machines should be placed in opposite places to save on transport between stations. Changing the position of machines does not involve any costs, but it can increase profits generated from the time saved.

2. Overproduction - creating stocks of small items that are in storage - the company should create production plans that take into account the demand for a given product. It often happens that employees produce items such as hangers or hooks in excess, without taking into account the actual demand for individual items at a given time. These products take up little space in the warehouse, but they still take up space that could be used for a more beneficial purpose.

3. Inventories - too many intermediates purchased by the company. The production manager often orders semi-finished products in advance, without taking into account the content of the warehouse and the demand.

4. Expectation - the welder is too loaded with the machine needed to manufacture most products, so you could buy a second or refine the production schedule to evenly distribute its use.

5. Unnecessary traffic (people) - the packaging hall should be synchronized with the main hall and receive orders automatically. An integrated management system could be used to improve people's work and eliminate unnecessary employee movements.

Most of the proposed improvements do not require financial expenditures, therefore it can be successfully used in a research facility.

\section{DISCUSSION}

Nowadays, the quality of services provided in all branches of the economy is of particular importance (Rosak-Szyrocka, 2016). Organizations operating in business are constantly looking for new tools, methods and systems in order to maximize profits and strengthen their competitive advantage. Improving all areas of the company is important because it allows you to increase its efficiency. As he notes (Wolniak, 2014; Ulewicz, 2016), improvement of the quality management system contributes to the reduction of costs. The investment in subordinates is an excellent procedure for increasing work efficiency. Confirmation of the growing importance of intangible assets in the valuation of the organization are the results of analyzes presented by OCEAN TOMO - The Intellectual Capital Merchant Banc ${ }^{\mathrm{TM}}$ from 2015. The analysis results show that the largest asset of the surveyed 500 largest corporations in the world are their employees. The conducted research was based on the index S \& P 500, which includes 500 companies with the largest capitalization listed on the New York Stock Exchange and NASDAQ, these are mainly American companies. The change regarding the valuation of the 500 largest corporations in the world, the value of which has evolved from the share of $83 \%$ of tangible assets in its valuation in 1975 to the value of $87 \%$ of intangible assets in 2015, allows to recognize that people (employees) are the largest "driving force" of value every organization (Roszak, 2016). The analysis of issues related to waste allows to conclude that the search and elimination of various types of waste despite the initial investment outlays, in the end results in large savings and profits resulting from shortening the time, cycles, roads and quantities of stored finished products and semi-finished products.

\section{CONCLUSION}

Analysis of quality problems based on traditional quality management tools allows to state that in the event of breaking the finished hook, which is the cause of the material, consult the 
producers to help select another, perhaps better, type of material. Further analysis allows to conclude that machine failures can be compensated by frequent technical inspections of devices after business hours. This activity generates costs related to the remuneration of specialists, but at the same time reduces the losses of time and money related directly to the stoppage of the plant. Errors from employee behavior can also be minimized by referring them to additional training. Such a procedure introduces freshness in the gaze of a given person into a specific process, allows for perceiving mistakes from a different perspective and introduces new habits in the behavior of the crew.

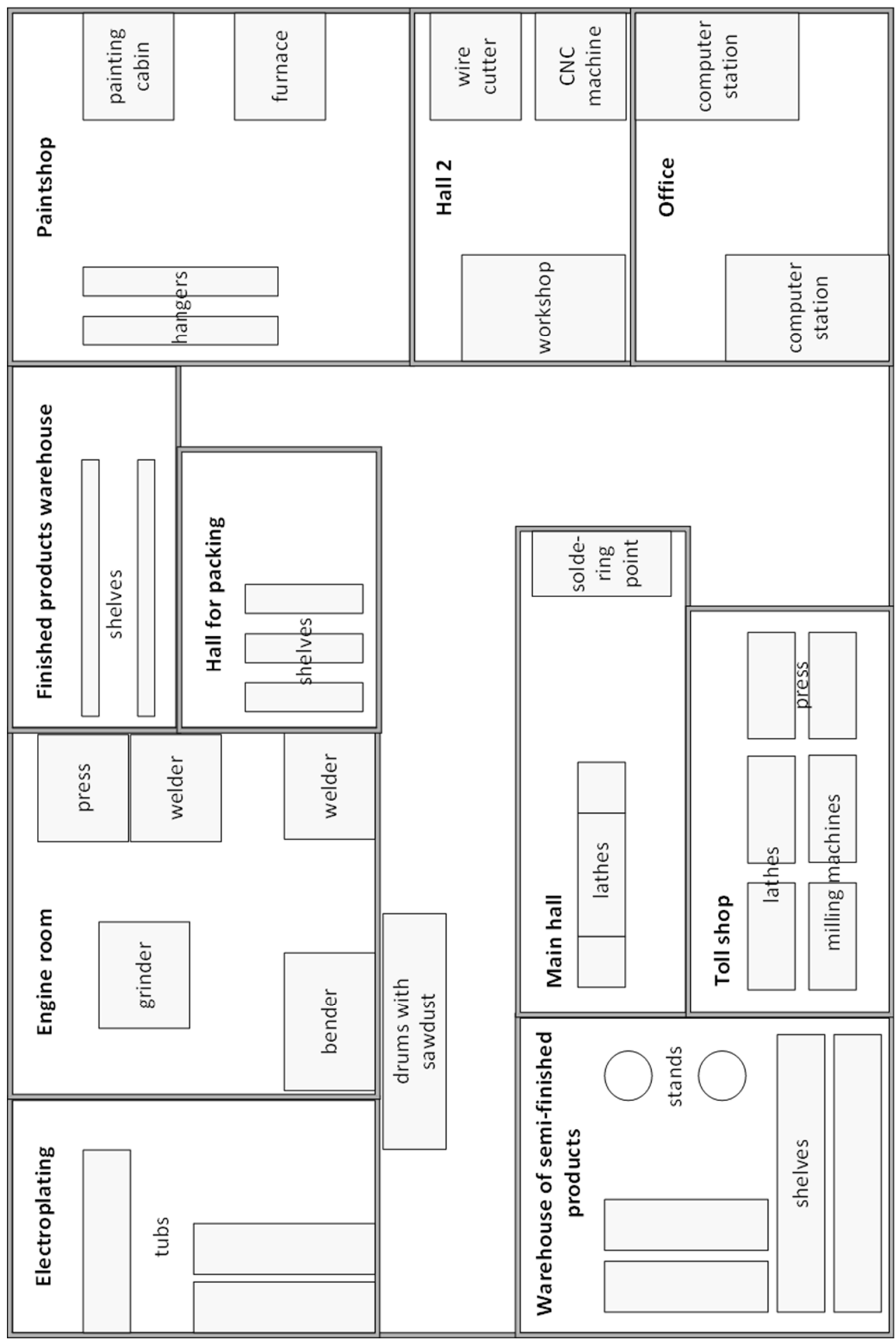

Fig. 3. Company's organization 


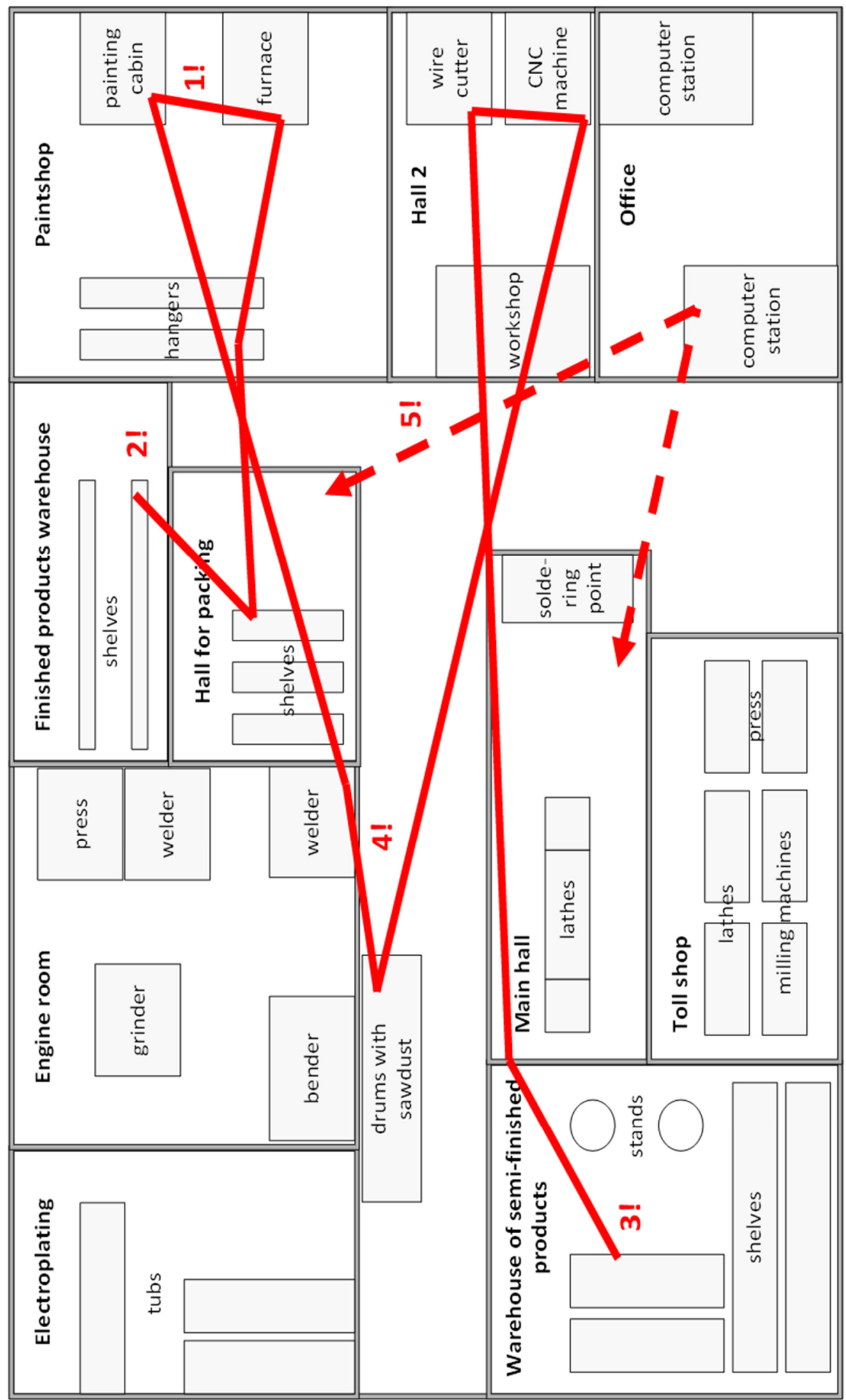

Fig. 4. Organization of an enterprise with places generating losses 


\section{REFERENCES}

Czubała, A. (2006). Usługi w gospodarce. In: A. Czubała. Ed., Marketing usług. Kraków: Wolters Kluwer Oficyna Ekonomiczna,.

Dobiegała-Korona, S., Kasiewicz, B. (2000). Metody Oceny Konkurencyjności Przedsiębiorstw. In: K. Kuciński, ed., Uwarunkowania Konkurencyjności Przedsiębiorstw W Polsce. Materiały i Prace IFGN, LXXIX. Warszawa: Oficyna Wydawnicza SGH.

Du, Q., Pan, M., Hu, J., Chen, D., Hu, J., Tian, Wugang, S., Kun (2018). Quality Factor Determination And Improvement Of Piezoelectric Driving Multilayer Resonator. Journal Of Micromechanics And Microengineering, 28(9).

Hamrol, A. (2008). Zarządzanie jakością z przykładami. Warszawa: Wydawnictwo Naukowe PWN,.

Hoag, B., Cooper, C.L. (2006). Managing value-based organizations: it's not what you think. Northampton: Edward Elgar Publishing Limited.

Jazon, A. (2002). Doskonalenie zarządzania jakością. Bydgoszcz: Oficyna Wydawnicza Ośrodka Postępu Organizacyjnego.

Juchnowicz, M. (2010). Zarządzanie przez zaangażowanie. Koncepcja. Kontrowersje, Aplikacje, PWE, Warszawa.

Kacała J., Wierzbic, A. (2015). Od systemów znormalizowanych do doskonałości biznesowej.

Malara, Z. (2000). Metody i doskonalenie organizacji i zarządzania przedsiębiorstwem: z teorii i praktyki. Bydgoszcz: Oficyna Wydawnicza Ośrodka Postępu Organizacyjnego.

Marchwinski, C., Shook, J. (2014). Lean Lexicon. Lean Enterprise Institute Inc. Cambridge. Management Forum, 3(4), pp. 28-32.

Ocean Tomo (2015). Annual Study of Intangible Asset Market Value from Ocean Tomo LLC. http://www.oceantomo.com/2015/03/04/2015-intangible-asset-market-value-study [Accessed 18 June 2018].]

Priede, J. (2012). Implementation of Quality Management System ISO 9001 in the World and Its Strategic Necessity. Procedia - Social and Behavioral Sciences, 58, pp. 1466-1475.

Rosak-Szyrocka, J. (2016). Konkurencyjność Usług Medycznych W Aspekcie Systemów Jakości. Toruń: Dom Organizatora, Towarzystwo Naukowe Organizacji i Kierownictwa.

Roszak, M. (2016). Zarządzanie Wiedzą Jako Czynnik Kształtujący Wartość Dodaną Organizacji. In: J. Rosak-Szyrocka, A. Sokół, M. Roszak, reds., Materialne i niematerialne źródła tworzenia wartości - wybrane zagadnienia z zarządzania i ekonomii. Celje: University Of Maribor.

Stasiak Betlejewska, R. - Czajkowska, A. (2017). Quantification of the Quality Problems in the Construction Machinery Production. 4th International Conference on Computing and Solutions in Manufacturing Engineering 2016.

Ulewicz, R 2016. Quality management system operation in the woodworking industry, Path Forward For Wood Products: A Global Perspective. Proceedings Of Scientific Papers, 2016, pp. 51-56.

Wolniak, R. (2014). Korzyści Doskonalenia Systemów Zarządzania Jakością Opartych O Wymagania Normy ISO 9001:2008. Problemy Jakości, 3, pp. 20-25.

Womack, J. P., Jones D. T. (2008). Lean Thinking - Banish Waste and Create Wealth in your Corporation. Journal of the Operational Research Society, 48, 1997(11), pp. 1144-1150. 